\title{
Feasibility Study and Techno-Economic Analysis of Stand-Alone Hybrid Energy System for Muğla Province Köyceğiz
}

\author{
Aykut Fatih GÜVEN ${ }^{*}$, Emre POYRAZ ${ }^{2}$
}

\begin{abstract}
In this study, technoeconomic analyses and environmental comparisons of various hybrid systems that will ensure that electricity needs are met independently of the grid of Köyceğiz district of Mugla, which has a population of about 40,000, were made. The unit energy cost of the hybrid energy system consisting of Solar Panel-Wind Turbine and Battery, which is planned to meet the electricity needs of the district with an average daily electricity consumption of $150,000 \mathrm{kWh}$, has been made net present value calculations. Homer (Hybrid Optimization Model for Electric Renewable) program was used to make these analyses. During the evaluations, various parameters (generator working load, wind turbine tower height, battery operating intervals, etc.) were changed for the system to be installed and sensitivity analyses were made. As a result of the study, the unit energy cost of the system, which can be installed independently of the grid, was calculated as $\$ 0.182 / \mathrm{kWh}$. Environmentally renewable and sustainable is the positive side of these systems. In addition, it has been observed that the cost decreases when parameters such as fuel cost, discount and inflation rates change.
\end{abstract}

Keywords: Hybrid Renewable Energy Systems, Technoeconomic Feasibility Analysis, HOMER.

\section{Muğla İli Köyceğiz İlçesinin Elektrik İhtiyacının Hibrit Enerji Sistemleri İle Karşılanması ve Teknoekonomik Açıdan İncelenmesi}

\section{$\ddot{\mathbf{O z}}$}

Bu çalışmada yaklaşık 40.000 nüfuslu Muğla ili Köyceğiz ilçesinin şebekeden bağımsız bir şekilde elektrik ihtiyacının karşılanmasını sağlayacak çeşitli hibrit sistemlerin teknoekonomik analizleri ve çevresel karşılaştırmaları yapılmıştır. Günlük ortalama elektrik tüketimi $150.000 \mathrm{kWh}$ olan ilçenin, elektrik ihtiyacının karşılanması için planlanan Güneş Paneli-Rüzgâr Türbini ve Bataryadan oluşan hibrit enerji sisteminin birim enerji maliyeti, net bugünkü değer hesapları yapılmıştır. Bu analizlerin yapımında HOMER (Hybrid Optimization Model for Electric Renewable) programdan faydalanılmıştır. Değerlendirmeler yapılırken de kurulacak sistem için çeşitli parametreler (jeneratör çalışma yükü, rüzgâr türbini kule yüksekliği, bataryaların çalışma aralıkları vb..) değiştirilerek hassasiyet analizleri yapılmıştır. Çalışmanın sonucunda şebekeden bağımsız kurulabilecek sistemin birim enerji maliyeti 0,182 \$/kWh olarak hesaplanmıştır. Çevresel anlamda yenilenebilir ve sürdürülebilir olması bu sistemlerin olumlu tarafıdır. Ayrıca yakıt maliyeti, indirim ve enflasyon oranları gibi parametrelerin değiştiği durumlarda da maliyetin azaldığı gözlemlenmiştir.

Anahtar Kelimeler: Hibrit Yenilenebilir Enerji Sistemleri, Teknoekonomik Fizibilite Analizi, HOMER.

\footnotetext{
${ }^{1}$ Yalova University, Department of Energy Systems Engineering, Yalova, Turkey, afatih.guven@yalova.edu.tr

${ }^{2}$ Yalova University, Department of Energy Systems Engineering, Yalova, Turkey, emrepoyraz1996@gmail.com
}

${ }^{1}$ https://orcid.org/0000-0002-1071-9700 ${ }^{2}$ https://orcid.org/0000-0002-7970-2894 


\section{Introduction}

With the developing technology and industrialization, the use and need of energy in the world is increasing day by day. Countries primarily use fossil fuels to meet these needs. Usage rates of fossil fuels have been at the highest level due to the economic feasibility of the past years and the development and widespread use of production systems. However, the oil crisis that broke out towards the end of the 20th century has reduced the trust in fossil fuels and the life expectancy for the future has become a big problem. In addition, the negative impact of fossil fuels on the environment and causing global warming has significantly increased the demand and use of renewable energy. The fact that there is no issue such as the depletion of renewable energy sources and the homogeneous distribution of many renewable energy sources in the world has made renewable energy popular.

The important advantage of renewable energy sources is that they can form a hybrid system with other energy sources. Hybrid energy systems are generally systems in which two or more different energy generation systems work together to feed electrical or thermal load. There are hybrid renewable energy systems that can operate on the grid or independently from the grid. Systems that operate independently from the network are used together with diesel generators in order to obtain energy in rural areas and far from energy transmission lines.

The use of hybrid systems created by using renewable energy sources together provides many positive features. Utilizing the energy provided by the sun only during the daytime, the lack of continuous energy from wind energy restricts the use of these systems or ensures that this stored energy can be used when the system cannot produce energy by providing storage at high capacities. Demands for hybrid energy systems in which solar and wind energy are used together, which lead the sector in the use of renewable energy sources, are increasing day by day. In addition, the use of diesel generator systems besides solar and wind energy in hybrid systems prevents the continuous energy provided in the system, as well as the installation of unnecessary solar or wind energy and reduces the energy unit cost.

Similar studies have been conducted using Solar cells or PV, wind turbines, fuel cells (used either for energy conversion or as a storage unit) for different locations like islands in Dongfushan Island, farthest eastern inhabited island in China which relies on diesel generation to meet the energy demand. Integrating RES to improve energy reliance has been proposed for this island due to the unavailability of to meet the island's energy demand have been proposed in (B. Zhao et al., 2014). A case study has been conducted for integrating HRES considering PV arrays, wind turbines, and battery storage option to meet the electrical load demand at Catalina Island in California (H. Rui et al., 2011). 
In this study, it is aimed to design a hybrid system that will meet the electricity needs of a district with a population of 40,000 and to investigate and compare the technological and environmental effects of this system.

\section{Materials and Methods}

The location selected as the place where the project is in Turkey's Aegean province of Mugla Koycegiz Area $\left(36^{\circ} 97^{\prime} \mathrm{N}, 28^{\circ} 69^{\prime} \mathrm{E}\right)$ district. The research and data obtained were made for a district with a population of 40,000. 1-day electricity load requirement of this population has been taken as $150,000 \mathrm{kWh} /$ day. It has been determined that the peak power value of this district during the day is $27,849.90 \mathrm{~kW}$.

The amount of energy that can be produced by solar panels that will produce electricity from solar energy is directly related to the meteorological data of the region. The solar energy data of the region are taken from NASA's database, which is integrated into the HOMER program. As seen in Figure 1, the solar energy potential of the region is more in summer and less in winter than in summer. However, the daily solar energy potential throughout the year has been determined as $5.27 \mathrm{kWh} / \mathrm{m} 2$ / day.

Since the investment costs of wind turbines are very high, the wind speed profile of the area to be installed is very important. The wind speed profile of the region has been taken from NASA's database as in the solar energy potential and it has been observed that the average wind speed is 4.34 $\mathrm{m} / \mathrm{s}$. In cases where solar energy may be insufficient during the winter months, it is obvious that wind energy will complement these deficiencies and the two will complement each other. Due to these features, they have been the two most preferred energy sources in hybrid systems. The wind speed profile of the region is also shown in Figure 2.

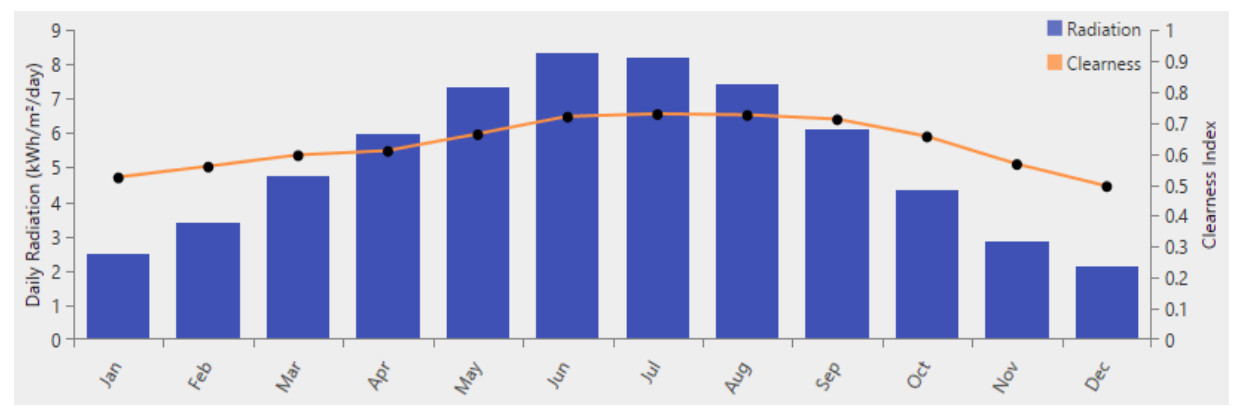

Figure 1. Solar irradiation and clearness index for the selected region 


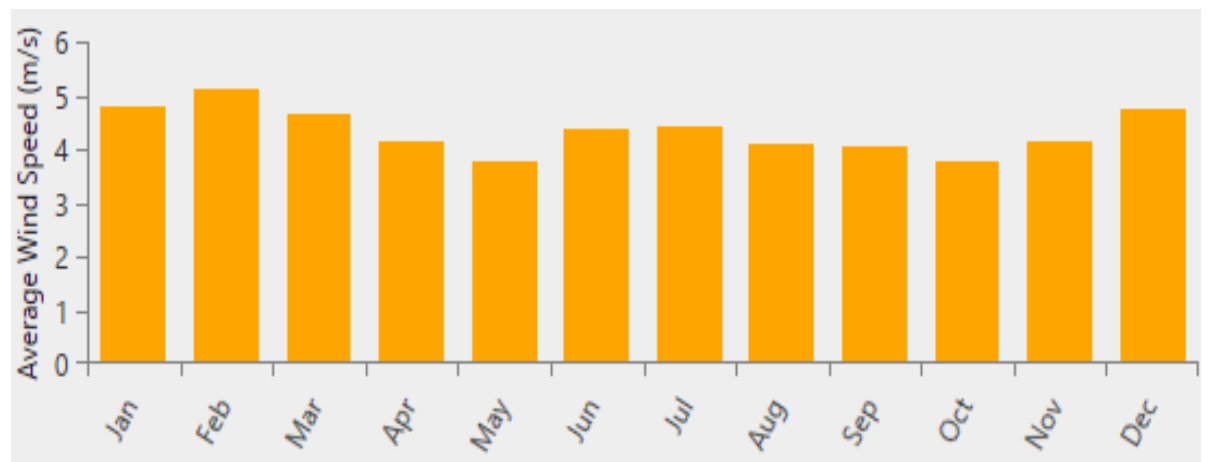

Figure 2. Wind speed for the selected region

2.1 HOMER (Hybrid Optimization of Multiple Electric Renewables) Program Used in Hybrid System Modeling

Homer is a program developed by the micro power optimization model NREL, which provides the most suitable budget system with the design of micro power systems and different combinations of different power supplies. Homer is the world's most advanced micro-grid modeling software. The physical behavior of the systems, the lifetime cost, which is the sum of the processing cost and the installation cost, and the energy unit cost, are found for different combinations. Although it is generally used for electricity generation, there are also heat generation applications. The models with / without energy storage connected to the grid / connected to the grid can be examined separately. In short, the HOMER program has developed various hybrid energy system models in different parts of the world and thanks to these models, it can find the most cost-effective hybrid energy system for the relevant geographic region. In doing so, it provides us with information about which hybrid energy system is more applicable in possible situations because of the different sensitivity analyzes it contains. The software can perform simulations of hundreds of data that can take many hours to ensure the optimum state between demand and supply to help design the best system. The diagram given in Figure 3 also shows the flow diagram for Homer software.

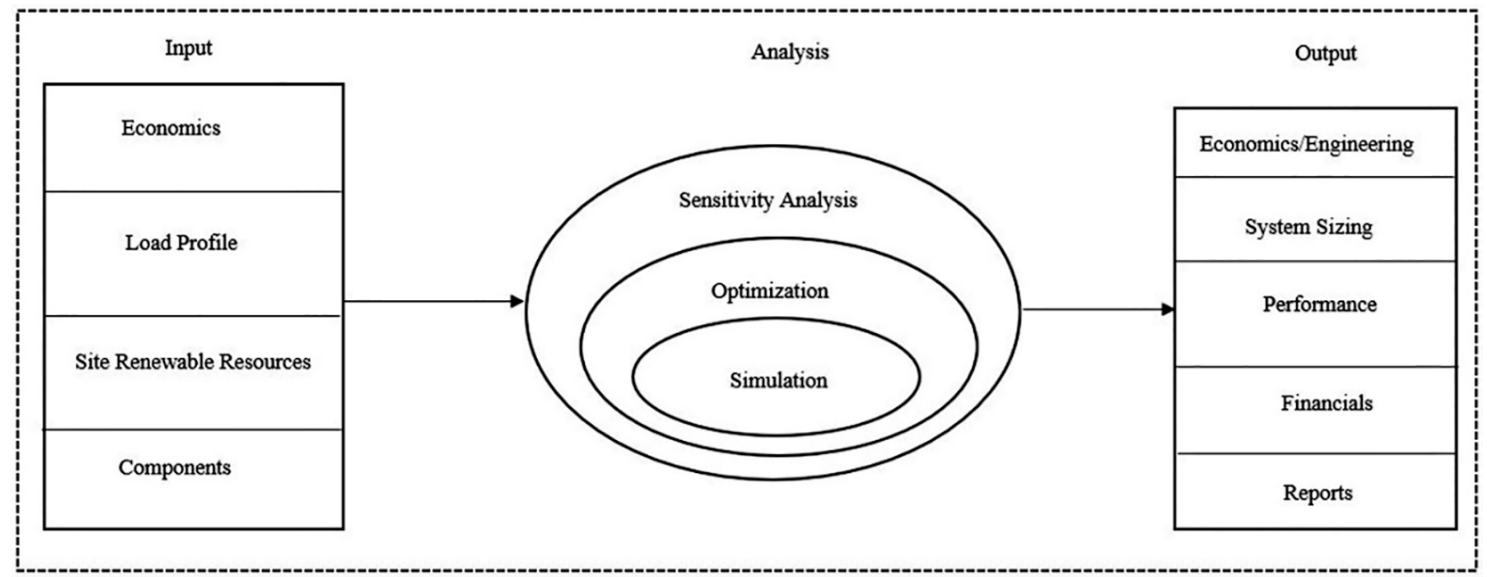

Figure 3. Flow-diagram for the homer software. 


\subsection{Components of the Hybrid System}

The basic components of the hybrid system to be designed can be written as solar panels, wind turbine, diesel generator, inverters and batteries. The inverter is for converting electrical power from $\mathrm{AC}$ or DC depending on the direction of power. The system needs an AC current and the battery also needs DC to charge. An inverter is added to optimize this power control and conversion. A diesel generator can be added to the system as a system element that is activated when all other components are deficient. All these components have been integrated into the system and simulated in the Homer program. In Figure 4, the schematic diagram of the system's Homer program is given.

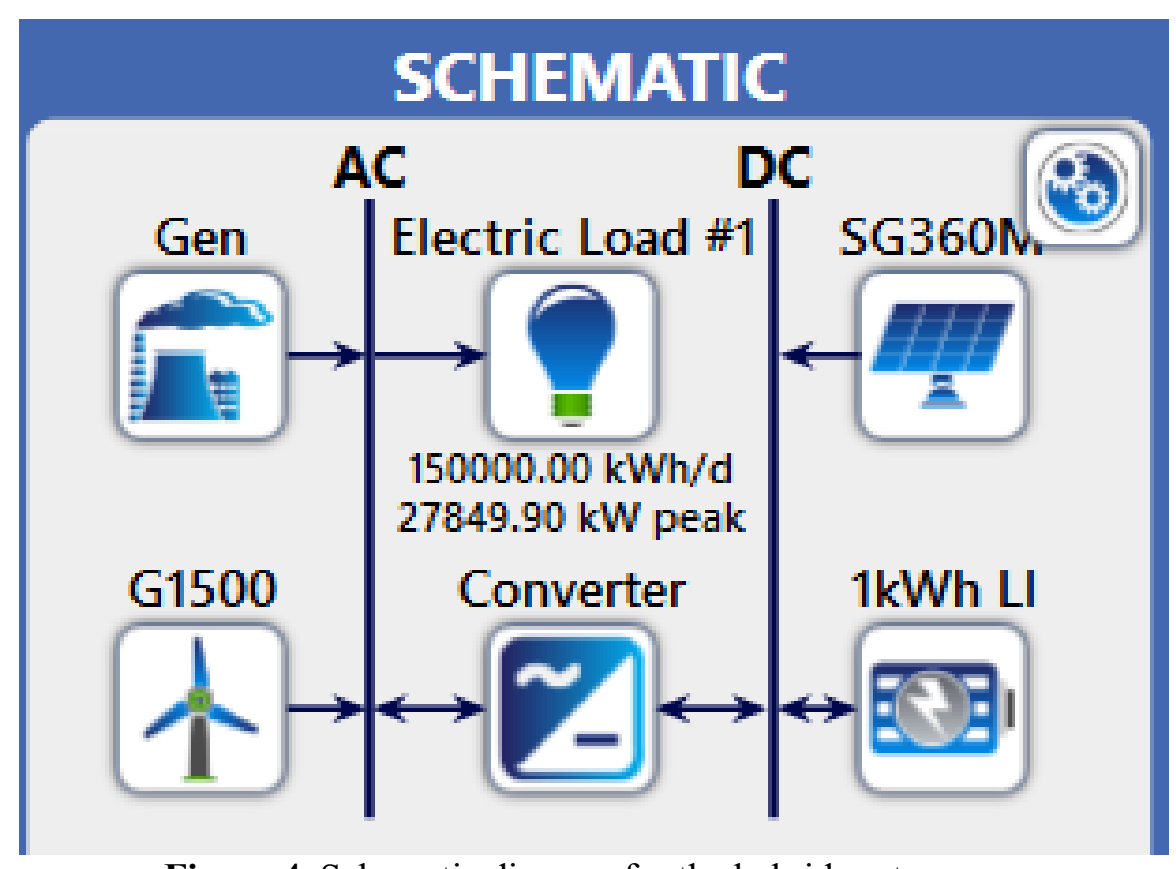

Figure 4. Schematic diagram for the hybrid system.

\subsubsection{Solar Panels}

Solar panels are one of the most important parts of hybrid systems, and they enable direct generation of electrical energy from the sun rays on the panel without any moving accents. Solar energy is the most important renewable energy source that has the capacity to meet the electricity needs of the whole world. The solar panel used in this system is one of the panels integrated with the HOMER program. And the most important parameter here is the cost per kW. The Peimar SG360M with generic solar panel was used for the evaluation, and the properties of the selected module is indicated in Table 1. 
Table 1. Technical parameters for the PV module.

\begin{tabular}{cc}
\hline Description & Value reference \\
\hline Panel type & Flat plate \\
Abbreviation & Peimar SG360M \\
Rated capacity $(\mathrm{kW})$ & 1 \\
Temperature coefficient & -0.352 \\
Operating temperature $(0 \mathrm{C})$ & 25 \\
Efficiency $(\%)$ & 18.5 \\
Capital cost $(\$ / \mathrm{kW})$ & 650 \\
Replacement cost $(\$ / \mathrm{kW})$ & 650 \\
O\&M cost $(\$ /$ year) & 40 \\
Lifetime (years) & 30 \\
\hline
\end{tabular}

\subsubsection{Wind Turbine}

Wind turbines are one of the most suitable systems for reducing the unit energy cost. However, since it is very high, it is not very suitable for power plant systems with sufficient capacity. Generic 1.5 MW wind turbine was used in this system. Technical Parameters are included in Table 2. The installation and maintenance cost of the turbine is $\$ 3$ Million, and the maintenance cost is $\$ 30,000$ / year. The graph of the output power-Wind Speed of the wind turbine is given in Figure 5.

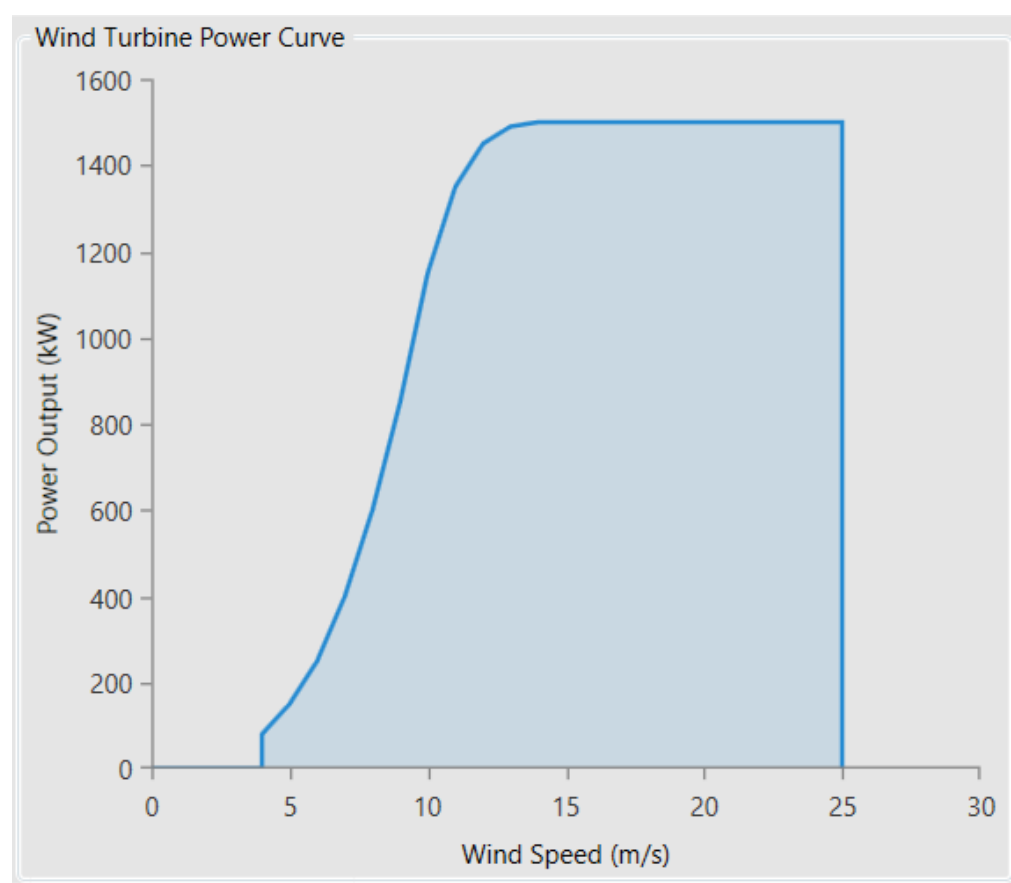

Figure 5. Power curve for the Generic [1.5 MW] wind turbine. 
Table 2. Technical parameters of the wind turbine.

\begin{tabular}{cc}
\hline Description & Value reference \\
\hline Manufacturer & Generic \\
Rated capacity $(\mathrm{kW})$ & 1500 \\
Rotor diameter $(\mathrm{m}$ & 80 \\
Hub height $(\mathrm{m})$ & 70 \\
Capital cost $(\$ \mathrm{~kW})$ & $3,000,000.00$ \\
Replacement cost $(\$ / \mathrm{kW})$ & $3,000,000.00$ \\
O\&M $(\$ /$ year $)$ Maliyeti $(\$ / \mathrm{y} 1)$ & $30,000.00$ \\
\hline
\end{tabular}

\subsubsection{Batteries}

Batteries are systems that store electrical energy in chemical form and are used for backup purposes. Here, they ensure that the energy produced by renewable energy sources is stored for the purpose of using the over-use in the following times. Lithium-Ion batteries with a capacity of $1 \mathrm{kWh}$ were also used in this system. Technical parameters of the battery are included in Table 3.

Table 3. Technical parameters of the battery.

\begin{tabular}{cc}
\hline Description & Value reference \\
\hline Nominal voltage(V) & 6 \\
Nominal capacity (Kwh) & 1 \\
Maximum capacity (Ah) & 167 \\
Round trip efficiency & 90 \\
Maximum charge current (A) & 167 \\
Maximum discharge current(A) & 500 \\
Quantity & 104,968 \\
Lifetime (Years) & 15.00 \\
Throughput $(\mathrm{kWh})$ & $3,000.00$ \\
Capital cost $(\$ \mathrm{kWh})$ & 550.00 \\
\hline
\end{tabular}

\subsubsection{Diesel Generator}

According to research, the cost per $\mathrm{kW}$ in diesel generators varies in the price range of $\$ 250$ to $\$ 500$. The cost value per $\mathrm{kW}$ in diesel generators decreases as power increases. The fuel consumption and efficiency graph of the diesel generator used is included in Figure 6 and Figure 7. The technical parameters of the generator are shown in Table 4. 
Table 4. Technical parameters for the generator.

\begin{tabular}{cc}
\hline Description & Value reference \\
\hline Fuel & Diesel \\
Capacity $(\mathrm{kW})$ & 1500 \\
Fuel curve intercept $(\mathrm{L} / \mathrm{hr})$ & 455 \\
Fuel curve slope $(\mathrm{L} / \mathrm{hr} / \mathrm{kW})$ & 0.236 \\
CO $(\mathrm{g} / \mathrm{L} /$ fuel $)$ & 16.5 \\
Unburned $\mathrm{HC}(\mathrm{g} / \mathrm{L}$ fuel $)$ & 0.72 \\
Particulates $(\mathrm{g} / \mathrm{L}$ fuel) & 0.1 \\
Fuel sulfur to PM $(\%)$ & 2.2 \\
NOX $(\mathrm{g} / \mathrm{L}$ fuel $)$ & 15.5 \\
Initial capital $(\$ / \mathrm{kW})$ & 500.00 \\
O\&M cost $(\$ / \mathrm{h})$ & 0.030 \\
Fuel price $(\$ / \mathrm{L})$ & 1.2 \\
\hline
\end{tabular}

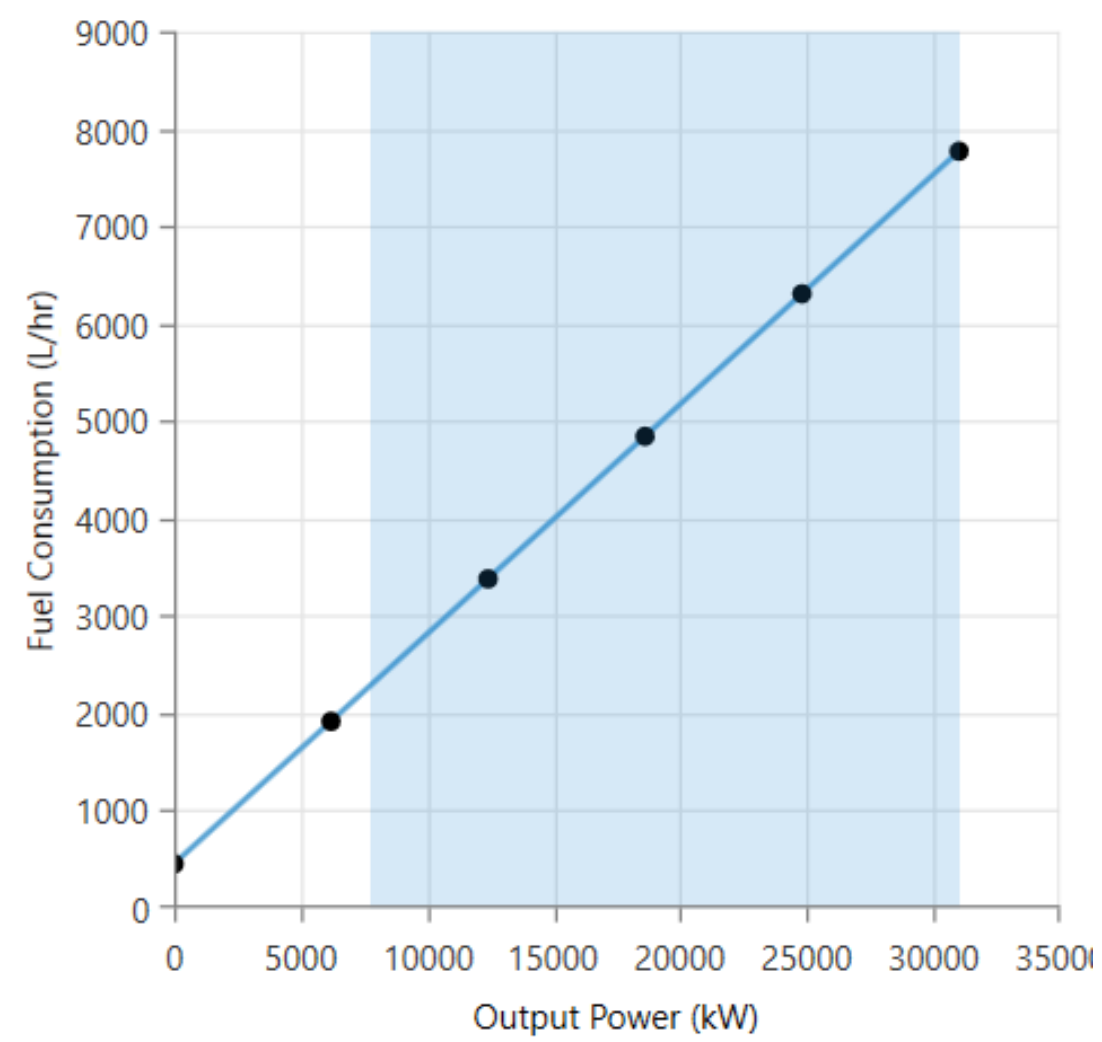

Figure 6. Fuel curve for the generator. 


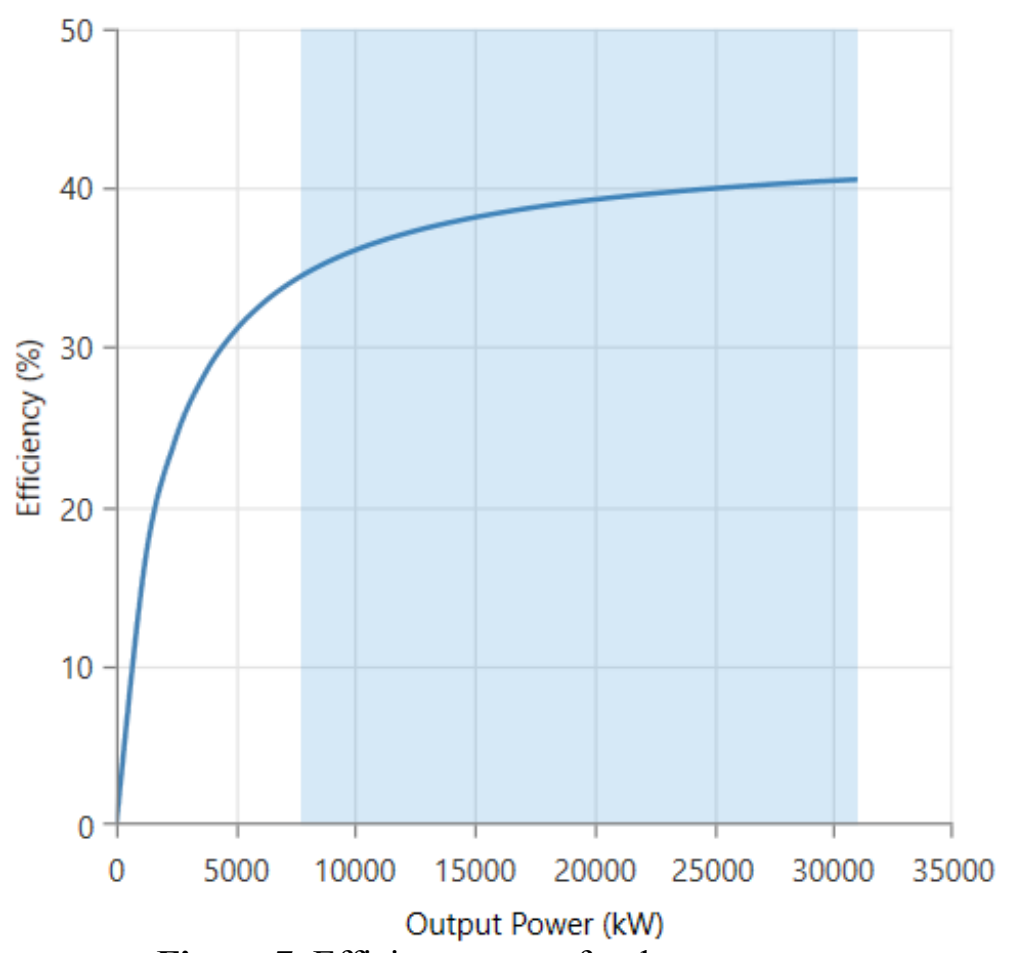

Figure 7. Efficiency curve for the generator.

\subsubsection{Converter}

The Studer Innotec SA AJ 700-48 converter with capacity of $1 \mathrm{~kW}$ was selected for this analysis. A capital cost of $\$ 300$, replacement cost of $\$ 300$ and O\&M cost of $20 \$ /$ year was used. It has a lifetime of 25 years

\subsection{Economic Analysis Inputs}

The HOMER program uses an annual actual interest rate when performing calculations per cost. The actual interest rate is calculated by the current interest rate and the use of inflation rates together. The actual annual interest rate can also be calculated as follows.

$\mathrm{i}=\left(\mathrm{i}^{\prime}-\mathrm{f}\right) /(1+\mathrm{f})$

Here;

i: Annual actual rate

$\mathrm{f}$ : Annual inflation rate

i': current interest rate

In this study, the current interest rate was taken as $17 \%$, the current inflation rate was $14 \%$, and the actual interest rate was calculated as $2.63 \%$. 


\subsection{Results of the Study and Discussion}

As a result of the simulations, multiple systems that can be installed for the selected region have been developed. As shown in Table 5 below, the results of the 6 most suitable system in terms of Renewable Fraction values are included. Using meteorological data of the region, wind turbine height was taken as $50 \mathrm{~m}$, diesel generator fuel price was $\$ 1.2$, commissioning load was taken as $25 \%$. In addition, cases where the generator produces only electricity and system loads are constant have been examined. However, the electricity consumption of the district during the day is $150,000 \mathrm{kWh}$ and the peak load value is $27.849 \mathrm{kWh}$ and shown in figure 8 . In addition, Figure 9 has monthly load profiles of electricity consumption.

Table 5. List of hybrid energy models resulting from simulation.

\begin{tabular}{|c|c|c|c|c|c|c|c|c|c|c|c|c|c|c|c|c|c|c|c|c|}
\hline \multicolumn{3}{|c|}{ Export... } & \multicolumn{16}{|c|}{$\begin{array}{l}\text { Optimization Results } \\
\text { Leff Double Click on a particular rsytem to see its detailed Simulation Results. }\end{array}$} & \multicolumn{2}{|c|}{ (-) Categorized () Over. } \\
\hline \multicolumn{9}{|c|}{ Architecture } & \multicolumn{4}{|c|}{ Cost } & \multicolumn{2}{|c|}{ System } & \multicolumn{5}{|c|}{ Gen } & \multirow{2}{*}{$\begin{array}{c}\text { Sc } \\
\text { Capital Cost, } \\
(\$)\end{array}$} \\
\hline$m+$ & $\pi$ & 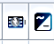 & ${ }_{(\mathrm{kW})}^{\mathrm{SG} 360 \mathrm{M}} \nabla$ & $61500 \nabla$ & $\begin{array}{l}\text { Gen } \\
(\mathrm{kW})\end{array}$ & $1 \mathrm{kWh} \iota \nabla$ & $\begin{array}{c}\text { Converter } \\
(\mathrm{kW})\end{array}$ & Dispatch $\nabla$ & ${ }_{(\$)}^{N P C} \odot \nabla$ & ${ }_{(s)}^{\mathrm{COE}} \odot \nabla$ & \begin{tabular}{|c|}
$\begin{array}{c}\text { Operating cost } \\
(\$ / / y r)\end{array}$ \\
$\nabla$
\end{tabular} & $\begin{array}{l}\text { Initial capital } \\
\text { (s) }\end{array}$ & $\begin{array}{l}\text { Ren Frac } \\
(\%)\end{array}$ & $\begin{array}{l}\text { Total Fuel } \\
(\text { (L/yr) }\end{array}$ & Hours $\nabla$ & $\mid \begin{array}{c}\text { Production } \\
(k W h)\end{array}$ & $\begin{array}{l}\text { Fuel } \\
\text { (L) }\end{array}$ & 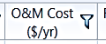 & $\begin{array}{l}\text { Fuel Cost } \\
(\$(y))\end{array}$ & \\
\hline Th & & z & 51,761 & 8 & & 104,968 & 19,575 & $\propto$ & $\$ 176 \mathrm{M}$ & $\$ 0.182$ & $\$ 3.01 \mathrm{M}$ & $\$ 121 \mathrm{M}$ & 100 & 0 & & & & & & $33,644,936$ \\
\hline$m$ & & 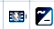 & 81,338 & & & 134,824 & 26,775 & 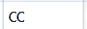 & $\$ 195 \mathrm{M}$ & $\$ 0.204$ & $\$ 3.32 \mathrm{M}$ & $\$ 135 \mathrm{M}$ & 100 & 0 & & & & & & $52,869,676$ \\
\hline$m+$ & E & ( & 48,235 & 8 & 31,000 & 105,440 & 22,493 & LF & $\$ 207 \mathrm{M}$ & $\$ 0.208$ & $\$ 3.92 \mathrm{M}$ & $\$ 136 \mathrm{M}$ & 95.7 & 695,070 & 300 & $2,367,404$ & 695,070 & 279,000 & 834,083 & $31,352,602$ \\
\hline$m$ & 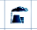 & 7 & 72,917 & & 31,000 & 125,000 & 23,789 & LF & $\$ 227 \mathrm{M}$ & $\$ 0.228$ & $\$ 4.85 \mathrm{M}$ & $\$ 139 \mathrm{M}$ & 94.0 & 958,285 & 410 & $3,270,865$ & 958,285 & 381,300 & $1,149,942$ & $47,396,148$ \\
\hline 个 & $=$ & [ & & 25 & 31,000 & 86,252 & 18,155 & $\propto c$ & $\$ 332 \mathrm{M}$ & $\$ 0.334$ & $\$ 10.4 \mathrm{M}$ & $\$ 143 \mathrm{M}$ & 67.5 & $4,519,864$ & 701 & 17,803,098 & $4,519,864$ & 651,930 & $5,423,838$ & \\
\hline$\uparrow$ & & $\boldsymbol{7}$ & & 49 & & 222,488 & 34,800 & cC & $\$ 438 \mathrm{M}$ & $\$ 0.461$ & $\$ 8.73 \mathrm{M}$ & $\$ 280 \mathrm{M}$ & 100 & 0 & & & & & & \\
\hline & 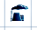 & ( & & & 31,000 & 46,036 & 17,255 & $\propto c$ & $\$ 567 \mathrm{M}$ & $\$ 0.571$ & $\$ 28.7 \mathrm{M}$ & $\$ 46.0 \mathrm{M}$ & 0 & $15,682,981$ & 2,533 & $61,579,004$ & $15,682,981$ & $2,355,690$ & $18,819,578$ & \\
\hline Th & $=$ & & 105,154 & 28 & 31,000 & & 13,105 & $\propto c$ & $\$ 571 \mathrm{M}$ & $\$ 0.575$ & $\$ 22.0 \mathrm{M}$ & $\$ 172 M$ & 35.0 & $10,405,425$ & 4,408 & $35,600,990$ & $10,405,425$ & $5,099,440$ & $12,486,509$ & $68,350,184$ \\
\hline m & $=$ & & 75,376 & & 31,000 & & 15,665 & cc & $\$ 632 \mathrm{M}$ & $\$ 0.636$ & $\$ 28.2 \mathrm{M}$ & $\$ 121 \mathrm{M}$ & 8.52 & $14,545,880$ & 5,997 & $50,085,040$ & $14,545,880$ & $5,577,210$ & $17,455,056$ & $100,344,416$ \\
\hline t & 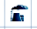 & & & 41 & 31,000 & & & CC & $\$ 653 \mathrm{M}$ & $\$ 0.657$ & $\$ 28.4 \mathrm{M}$ & $\$ 139 \mathrm{M}$ & 18.4 & $13,024,549$ & 5,446 & $44,699,843$ & $13,024,549$ & $5,064,780$ & $15,629,459$ & \\
\hline
\end{tabular}

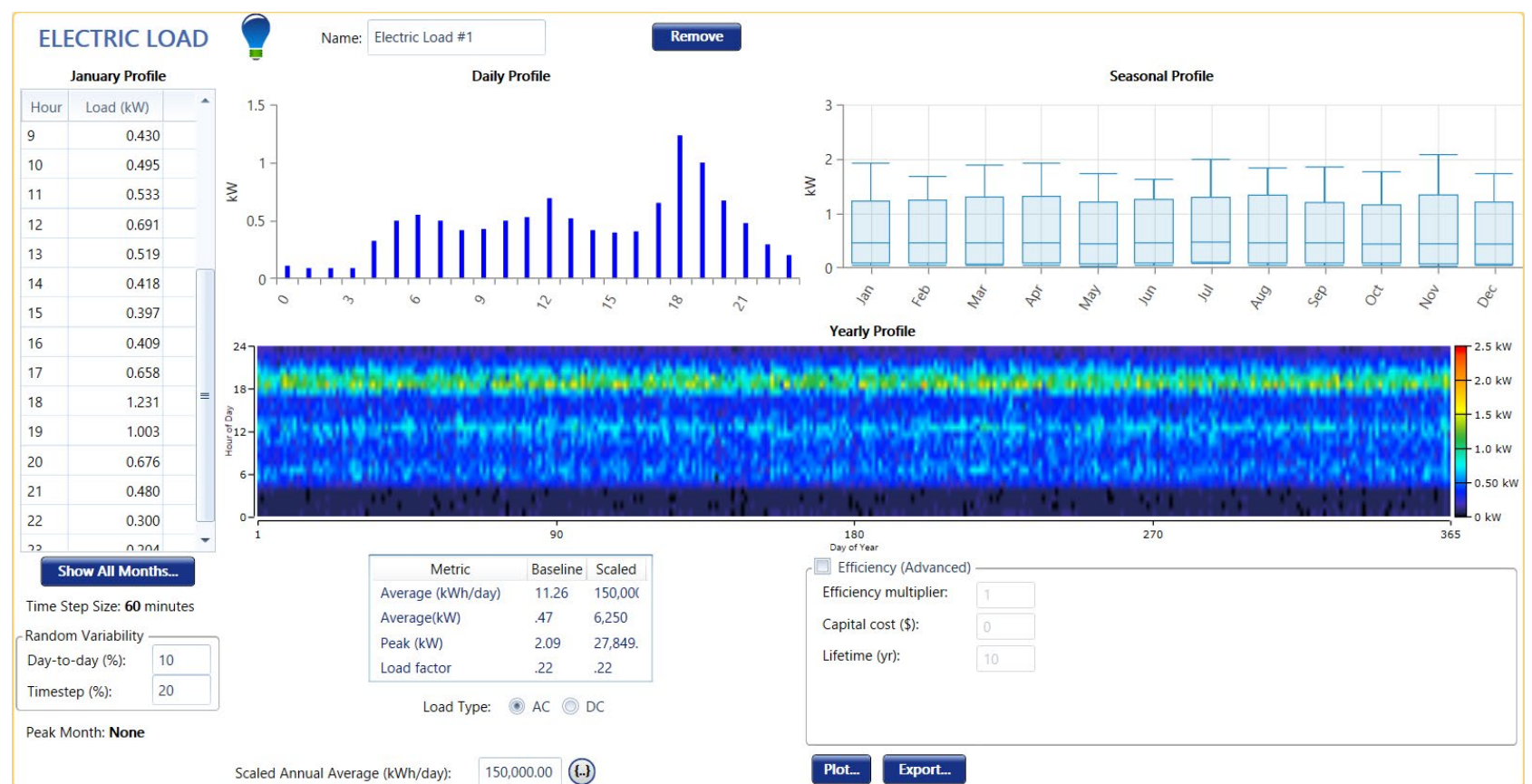

Figure 8. Profiles for electric charge 

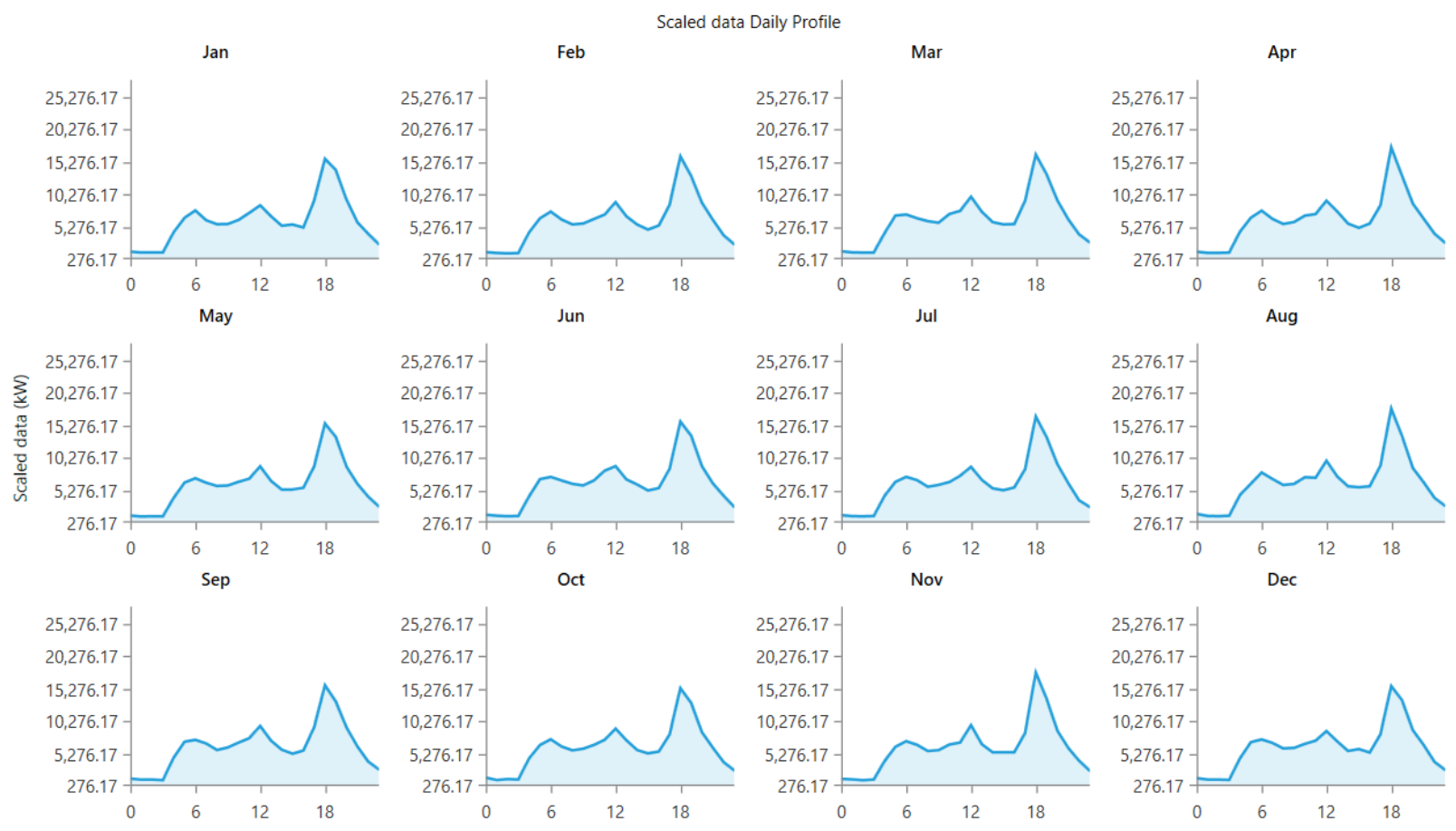

Figure 9. Monthly load profile of electricity consumption

\subsection{Economic and Technical Analysis}

The most appropriate value was obtained because of simulation for the specified region. Unit energy cost is calculated as $\$ 0.182$. It has a $100 \%$ renewable rate in terms of hybrid energy system. Table 6 contains cost values for the equipment and other components that make up the hybrid energy system. Annual and current net costs of system elements are also seen in Figure10 and Figure11.

Table 6. Table containing the system's cost information.

\begin{tabular}{|c|c|c|c|c|}
\hline Component & Capital (\$) & Replacement (\$) & O\&M (\$) & Total (\$) \\
\hline $\begin{array}{c}\text { Generic } 1.5 \\
\text { MW }\end{array}$ & $\$ 24,000,000.00$ & $\$ 14,275,490.31$ & $\$ 4,356,023.86$ & $\$ 33,228,929.67$ \\
\hline $\begin{array}{c}\text { Generic } \\
1 \mathrm{kWh} \text { Li- } \\
\text { Ion }\end{array}$ & $\$ 57,732,400.00$ & $\$ 39,139,726.38$ & $\$ 19,051,796.34$ & $\$ 105,994,518.35$ \\
\hline $\begin{array}{c}\text { Peimar } \\
\text { SG360M }\end{array}$ & $\$ 33,644,836.08$ & $\$ 0.00$ & $\$ 0.00$ & $\$ 30,715,684.10$ \\
\hline $\begin{array}{c}\text { System } \\
\text { Converter }\end{array}$ & $\$ 5,872,461.16$ & $\$ 0.00$ & $\$ 0.00$ & $\$ 5,872,461.16$ \\
\hline System & $\$ 121,249,697.24$ & $\$ 53,415,216.69$ & $\$ 23,407,820.19$ & $\$ 175,811,593.28$ \\
\hline
\end{tabular}




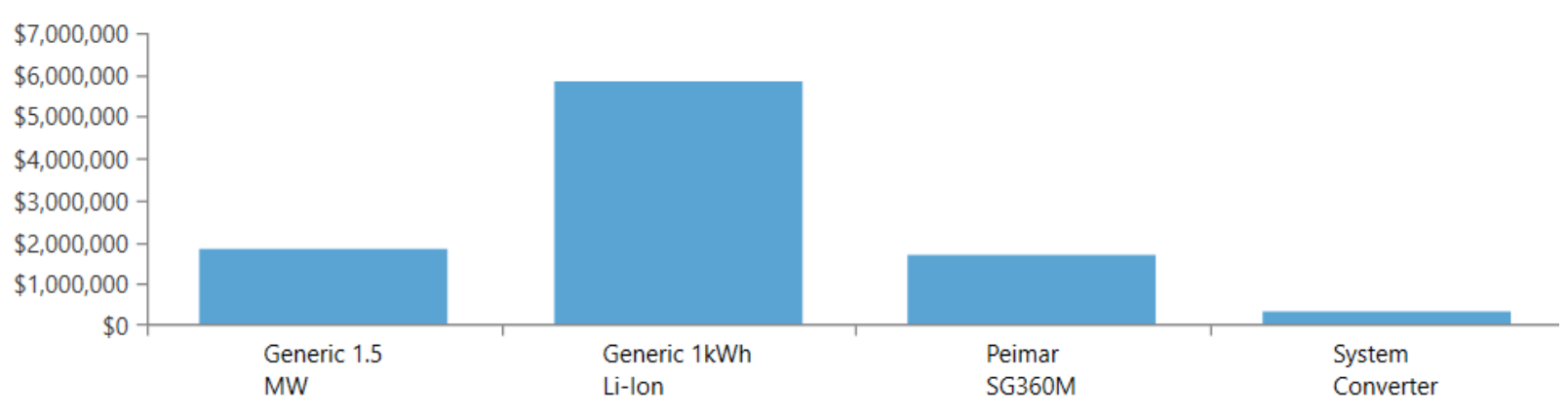

Figure 10. Annual costs of system elements

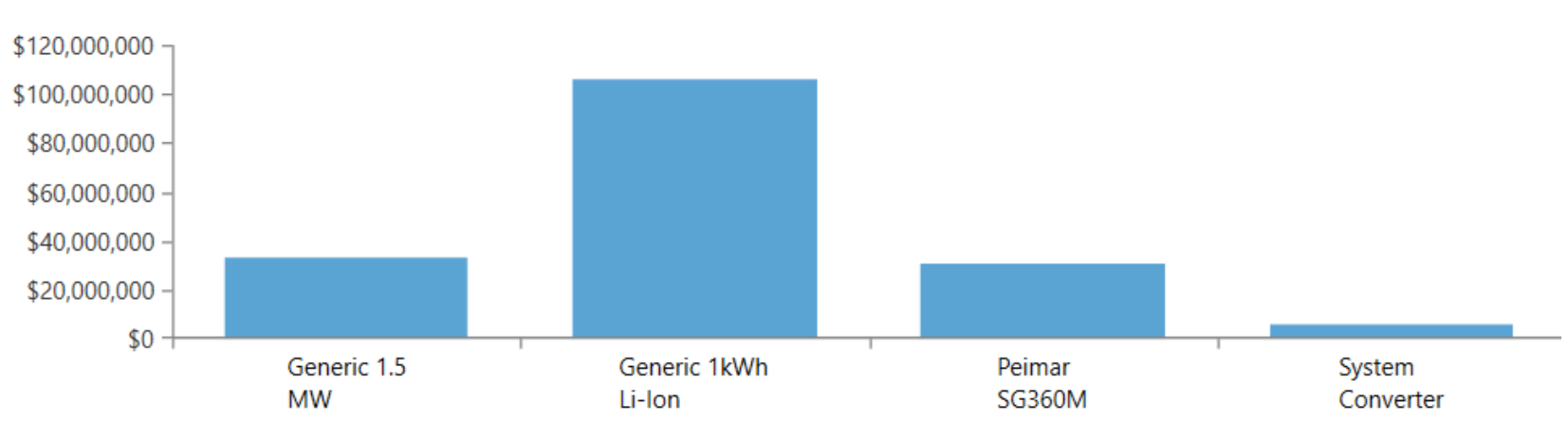

Figure 11. Current net costs of system elements

According to homer simulation results, compared to first system and second system, wind turbid was removed in second system. The most suitable solution was offered using 51,761 solar panels, 8 wind turbine, 104,968 batteries and 19,575 converters. The net present value of the first system was determined as $\$ 176 \mathrm{M}$, unit energy cost was $\$ 0.182$ and operating cost was $\$ 3.01 \mathrm{M}$. In the second system, it was seen that the wind turbine was removed. 81,338 solar panels, 134,824 batteries and 26,775 converters were used. The net present value of the second system is calculated as $\$ 195 \mathrm{M}$, unit energy cost is $\$ 0.204$ and operating cost is $\$ 3.32 \mathrm{M}$. In the third system, 48,235 solar panels, 8 wind turbine, 31,00 generators, 105,440 batteries and 22,493 in-house insurers are used. The net present value of the third system is calculated as $207 \mathrm{M} \$$, unit energy cost is $\$ 0.208$ and operating cost is $\$ 3.92 \mathrm{M}$.

Since an energy system that cannot be renewed enters the third system, the gases that will be released into the atmosphere bring a great disadvantage together. Although the renewable energy factor of first system and second system is $100 \%$, this value has decreased to $95.7 \%$ in third system. Due to the use of the diesel generator, various gases will be released into the atmosphere and clean energy will be waived. Table 7 contains emission values for gases released into the environment due to the use of diesel generators. The unit energy cost and net present value of the third system increased compared to the first system and second systems. Therefore, the selection of the first system is much cleaner and more convenient in every way. 
Table 7. Emission values of gases that the third system releases into the environment.

\begin{tabular}{cc}
\hline Toxic Emission & Value $(\mathrm{kg} / \mathrm{yr})$ \\
\hline Carbon Dioxide & $1,819,424$ \\
Carbon Monoxide & 11,469 \\
Unberned Hydrocarbons & 500 \\
Particulate Matter & 69,5 \\
Sulfur Dioxide & 4,455 \\
Nitrogen Oxides & 10,774 \\
\hline
\end{tabular}

\subsection{Effects of Battery Use on The System}

The use rate of batteries in network independent systems is high. Batteries are often not preferred on the grounds that they will increase the cost of the system. However, with the simulations carried out, it was seen that it contributed positively to the cost in the system. The general spread of solar density and wind speeds throughout the year increases the frequency of use of generators in battery-free systems. As shown in Table5, the unit energy cost in systems using batteries is $\$ 0.182$, while in systems where the battery is not used, this rate is $\$ 0.575$.

The electrical load requirement required for the system; the shapes related to the batteries that help to meet this electrical need are also given below. Figure12 shows the Hourly Electric Charge throughout the Year, the figure the Occupancy Rate of The Hourly Battery Benches for 13 Years, and the charging status of the figure 14 batteries during the year on an hourly day. It is also seen in figure 13, where the batteries reach $100 \%$ occupancy at noon when the sun's rays are intense and meet the need for the supply of loads in the remaining hours.

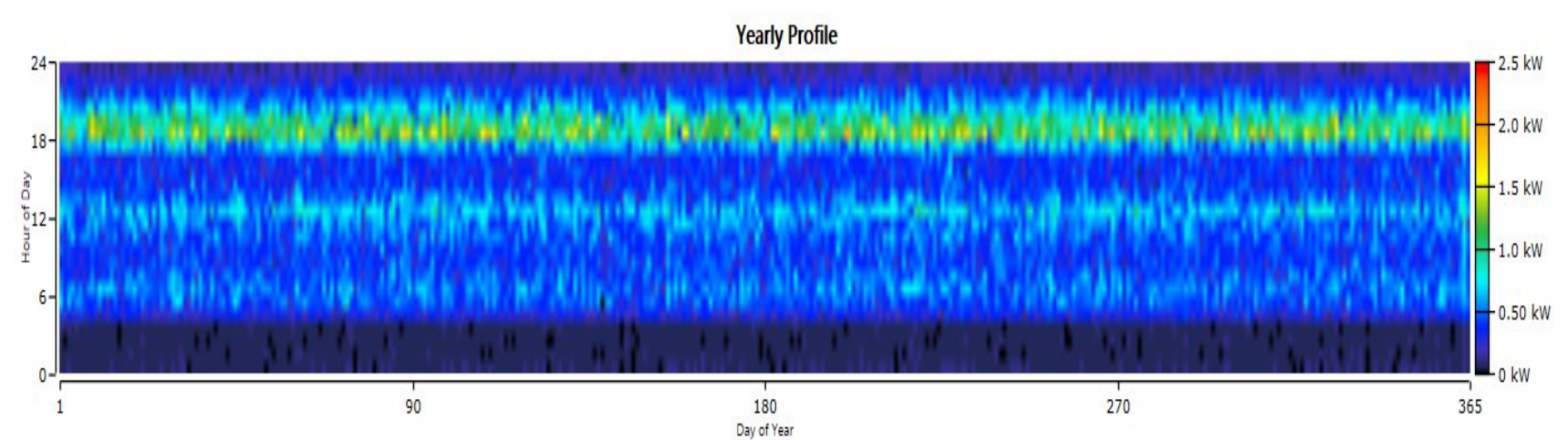

Figure 12. Yearly profile 


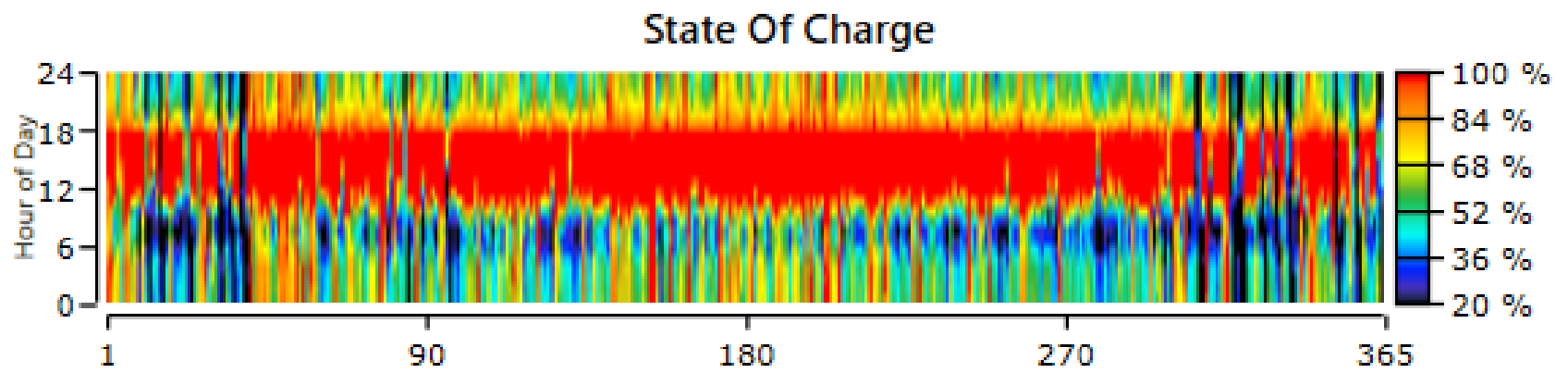

Figure 13. Yearly state of charge of battery for the hybrid system.

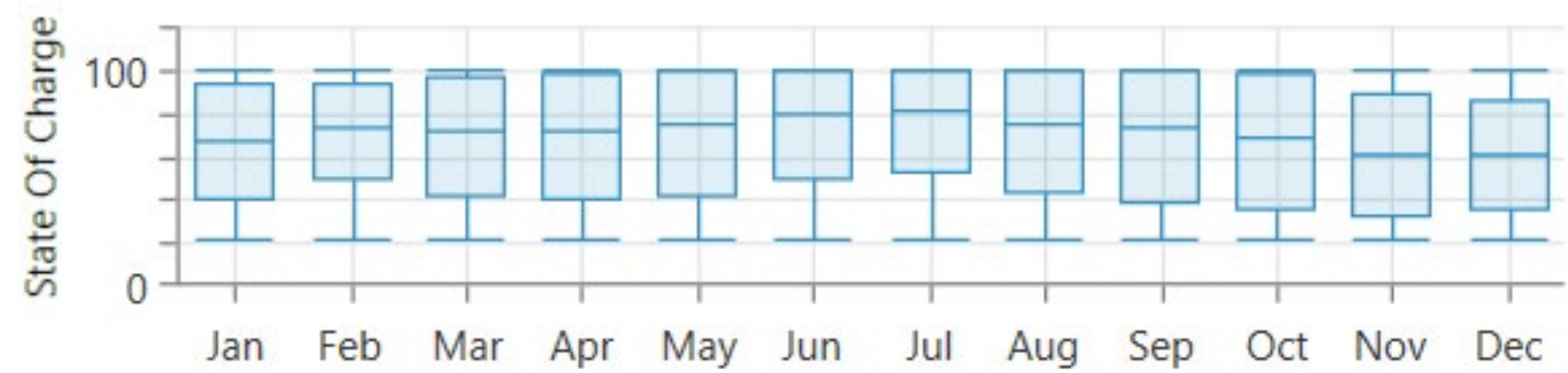

Figure 14. Monthly state of charge of battery for the hybrid system.

\subsection{Evaluation of All Optimization and Sensitivity Analysis}

As a result of all these data and analyzes, it increases system efficiency if the batteries are actively used in the system and the generator is operated at $25 \%$ capacity. In this selected system, all electricity production is provided by renewable energy sources. Figure 15 shows the electricity generation chart of renewable energy sources.

\begin{tabular}{|l|l|l|}
\hline Production & $\mathrm{kWh} / \mathrm{yr}$ & $\%$ \\
\hline Peimar SG360M & $90,267,173$ & 79.1 \\
\hline Generic 1.5 MW & $23,909,958$ & 20.9 \\
Total & $114,177,131$ & 100 \\
\hline
\end{tabular}

\begin{tabular}{|l|l|l|}
\hline Consumption & $\mathrm{kWh} / \mathrm{yr}$ & $\%$ \\
\hline AC Primary Load & $53,215,237$ & 100 \\
DC Primary Load & 0 & 0 \\
Deferrable Load & 0 & 0 \\
Total & $53,215,237$ & 100 \\
\hline
\end{tabular}

\begin{tabular}{|l|l|l|}
\hline Quantity & $\mathrm{kWh} / \mathrm{yr}$ & $\%$ \\
\hline Excess Electricity & $56,904,495$ & 49.8 \\
Unmet Electric Load & $1,534,763$ & 2.80 \\
Capacity Shortage & $2,776,590$ & 5.07 \\
\hline
\end{tabular}

\begin{tabular}{|l|l|l|}
\hline Quantity & Value & Units \\
\hline Renewable Fraction & 100 & $\%$ \\
Max. Renew. Penetration & 2,503 & $\%$ \\
\hline
\end{tabular}

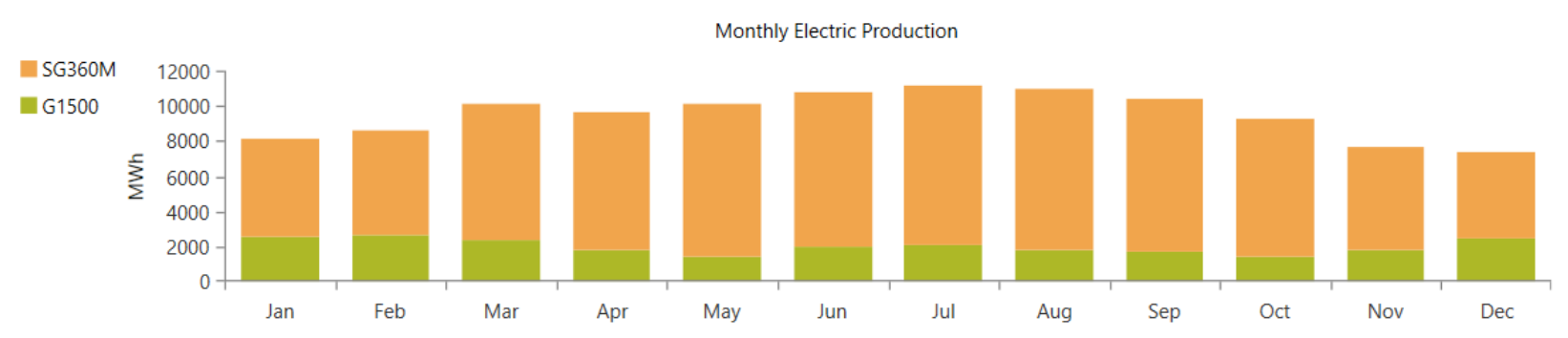

Figure 15. Electricity generation of solar and wind system 
As a result of the research, when the average solar radiation and wind speed in Turkey were taken into account, it was seen that these values could increase to $6.5 \mathrm{~m} / \mathrm{s}$ for wind speed and 5.5 $\mathrm{kWh} / \mathrm{m} 2 /$ day of average solar radiation. For locations that can meet these features, much more efficient and cost-effective hybrid systems can be designed. As shown above, the complete renewable of the first system selected from Table 5 (PV-Wind Turbine-Batteries) is a very positive result both environmentally and economically İngilizce çevirisi. The ability to meet the electrical needs of such a large system with solar panels and wind turbines is very important and pleasing for the use and development of renewable energy systems. However, the use of batteries in the system has made positive contributions to the system both in terms of cost and continuity. The presence of a battery system that can be activated in cases where wind turbines and solar panels are inadequate also prevents power outages. If a diesel generator is added to system1, as seen in Table 5 (PV-Wind Turbine-Diesel Generator-Batteries), it will reduce the number of solar panels in the system. However, the renewable energy rate of the system will decrease to $95.7 \%$. The increase in the cost of gases and unit energy to be released into the environment is seen among the negative sides of this system.

\section{Conclusions and Recommendations}

This study aims to reveal the techno-economic potential of a commercial hybrid energy system that will meet the electricity needs of the Muğla province Köyceğiz district with a population of approximately 40,000. Optimum design and operation strategy for Solar-Wind Turbine-Battery and Solar-Wind Turbine-Diesel Generator-Battery hybrid systems has been evaluated. Unit energy cost and capital cost are some of the basic parameters that investors take into account during feasibility studies. As a result of the calculations, the unit energy cost results obtained for the Solar-Wind Turbine-Battery hybrid system are $0.182 \$ / \mathrm{kWh}$ and the Solar-Wind Turbine-Diesel GeneratorBattery hybrid system is 0.208 \$ / kWh. Net present values of $176 \mathrm{M}$ \$ and $207 \mathrm{M}$ \$ were obtained for Solar-Wind Turbine-Battery and Solar-Wind-Diesel Generator-Battery systems, respectively. The unit energy cost obtained is reflected as $0.177 \$ / \mathrm{kWh}$ in the grid electricity pricing for the household consumers of Köyceğiz district.

From the sensitivity analysis, it is clear that the government and policymakers have a very important role to play in making the cost of electricity affordable for households and commercial consumers. One of the factors that has a significant impact on unit energy cost is fuel cost, and the cost of fuel in Turkey is determined by factors such as exchange rate, crude oil price and inflation among others. While some factors are out of the control of the Turkish government, the economic environment for investment can be created by controlling values such as inflation, discount rate and 
interest rates. In addition, the renewable energy law alone is not enough to attract both local and international investments to the sector. The government must make an informed effort by setting policies and strategies on the part of utility companies and energy sector players to help the industry thrive. In order to provide investors with a safe environment for their investments to grow, the commitment to the sector should transparently set specific policies. The creation of an investment environment may include, but is not limited to investment incentives, competitive tariff guarantee, sales tax exemptions for renewable energy equipment can be applied to promote the development of renewable energy.

It also reveals the fact that the unit cost of the energy produced by hybrid energy systems will be even cheaper than the energy conventionally produced as a result of the further development of technology and the decrease in renewable energy equipment costs. In addition to cost, electricity generation with $100 \%$ renewable energy sources also produces positive results from an environmental point of view.

\section{Authors' Contributions}

All authors contributed equally to the study

\section{Statement of Conflicts of Interest}

There is no conflict of interest between the authors.

\section{Statement of Research and Publication Ethics}

The author declares that this study complies with Research and Publication Ethics.

\section{References}

B. Zhao., X. Zhang., P. Li., K. Wang., M. Xue., and C. Wang, (2014). Optimal sizing, operating strategy and operational experience of a stand-alone microgrid on Dongfushan Island. Applied Energy, vol. 113, Pp. 1656-1666.

H. Rui., S. H. Low., U. Topcu., K. M. Chandy., and C. R. Clarke, (2011). Optimal design of hybrid energy system with PV/wind turbine/storage: A case study, Smart Grid Communications (SmartGridComm). IEEE International Conference on, Pp. 511-516. 